\title{
REVIEW
}

UDC 58.036:577/.112/.152.1./19:582.542.11

doi: https://doi.org/10.15407/ubj89.01.005

\section{LIPOXYGENASES AND THEIR METABOLITES IN FORMATION OF PLANT STRESS TOLERANCE}

\author{
L. M. BABENKO ${ }^{1}$, M. M. SHCHERBATIUK ${ }^{1}$, T. D. SKATERNA ${ }^{2}$, I. V. KOSAKIVSKA ${ }^{1}$ \\ ${ }^{1}$ M.G. Kholodny Institute of Botany, National Academy of Sciences of Ukraine, Kyiv; \\ ${ }^{2}$ Palladin Institute of Biochemistry, National Academy of Sciences of Ukraine, Kyiv; \\ e-mail: lilia.babenko@gmail.com
}

\begin{abstract}
The review focuses on the analysis of new information concerning molecular enzymology of lipoxygenases - proteins involved in lipid peroxidation and found in animals and plants. Modern concept of structural features, catalytic characteristics and functions of lipoxygenase family enzymes as well as products of their catalytic activity in plants have been discussed and summarized. Issues of enzyme localization in plant cells and tissues, evolution and distribution of lipoxygenases, involvement in production of signaling substances involved in formation of adaptation response to abiotic and biotic stress factors and in regulation of lipoxygenase signal system activity are highlighted. Participants of the elements signaling of LOX-pathway reception and transduction into genome are considered. Special attention is given to jasmonates, metabolites of the allene oxide synthase branch of the lipoxygenase cascade, because these metabolites have high biological activity, are ubiquitously present in all plant organisms, and are involved in regulation of vitally important processes. Data concerning lipoxygenase phylogeny, possible occurrence of a common predecessor for modern isoforms of the enzyme in pro- and eukaryote have been examined. Some results of our studies that open up possibilities of using the lipoxygenase catalytic activity characteristics as biological markers in plant stress tolerance researches are given.
\end{abstract}

Key words: lipoxygenase, structure, catalysis, jasmonic acid, abiotic/biotic stresses.

$\mathrm{P}$ lant vital activities are affected by various environmental factors. Some of them depending on their duration and intensity may act as stressors. Drought, frosts, high and low temperatures, high humidity, acidity and salinity of soils, pesticide pollution, etc. have a negative effect on growth and development, inhibit metabolism, change its pattern, apply internal energy for overcoming stress effects $[1,2]$. There are two main strategic responses to stressor effects: avoidance of stressor effects due to being in a physiologically inactive phase and formation of stress tolerance or adaptation [2,3]. Cell mechanisms of adaptation, physiological and metabolic restructuring, responses formation, role of individual compounds in alarm signal transduction have been actively studied in recent years. [1-4]. Among components involved in the formation of adaptive reactions a significant role is played by compounds of the lipoxygenase pathway (LOX-pathway) of polyunsaturated fatty acids (PUFA) oxidation, which possess the key signaling system characteristics: perception, signal transformation and augmentation, expression of defense genes $[5,6]$. LOX-pathways metabolites - oxylipins interact with other signaling pathways in plant cells, including signaling pathways of the plant hormones auxin, gibberellin, ethylene, abscisic acid (ABA) and salicylic acid (SA). The role of LOX metabolites in biotic stress responses has been described in many published works [7]. The role of oxylipins in plant adaptation to abiotic stress conditions is less studied; there is also obvious lack of available data compilation and analysis in this area of research [8]. The review aims to analyze and summarize modern data

(C) 2017 Babenko L. M. et al. This is an open-access article distributed under the terms of the Creative Commons Attribution License, which permits unrestricted use, distribution, and reproduction in any medium, provided the original author and source are credited. 
on the lipoxygenase family enzymes, their catalytic characteristics, localization in plant cells and tissues, features of lipoxygenase signaling system regulation, catalytic activity products, lipoxygenases evolution and distribution. Special attention is paid to the role of plant lipoxygenases and products of their metabolic pathways in the formation of stress tolerance in plants under abiotic stress.

\section{Lipoxygenase general characteristic}

Lipoxygenase was described in 1932 as an enzyme that oxidizes fatty acids, but studies on molecular and functional features of these enzymes started only in the mid-90s when the role of jasmonic acid (JA), one of the basic products of the LOX-pathway, in the regulation of plant physical-biochemical processes had been discovered and studied $[9,10]$. The lipoxygenase family (LOXs; EC 1.13.11.12) includes non-gemic iron-compatible dioxygenases, which catalyze regio- and stereo dioxygenation of polyunsaturated fatty acid (PUFA) with one or several cis, cis-1,4-pentadiene fragments and production of fatty acid hydroperoxides $[5,6,11]$. The mammal LOXs classification is based on the oxidation specificity of arachidonic acid. According to the produced products there are singled out 5-, 8-, 9-, 11-, 12- and 15-LOXs $[5,11]$. Stereospecificity of LOXs action is also taken into account: (S-) or (R-). LOXs plants are classified considering oxidation specificity of linoleic $(18: 2)$ and $\alpha$-linoleic $(18: 3)$ acids. There are iron- and manganese-compatible LOXs [12]. Molecular weight of higher plant LOXs is within the range of 94-100 kDa [13]. The isoform crystal structure of LOX-1 and LOX-3 isolated from Glycine max (L.) Merr. was studied [14]. LOXs molecules consist of two, different in size domains. The enzyme active center with one atom of non-gemic iron is located at the C-terminal domain that contains about $600 \mathrm{ami}-$ no acid residues. This domain molecular weight is in the range of 55-65 $\mathrm{kDa}$ [11]. X-ray diffraction and spectroscopic analyses of lipoxygenase from G. max showed that the iron coordination sphere looks like a tilted octahedron and consists of three histidine residues, C-terminal carboxyl group and asparagine residue $[11,15]$. With iron being in an active state $\left(\mathrm{Fe}^{3+}\right)$ the number of ligands was found to amount to six due to ion hydroxide. A high reduction potential of iron $(0.6 \mathrm{~V})$, located in the enzymeactive center, transforms LOX to a strong oxidizing agent [15]. The N-terminal domain contains about 150 amino acid residues that form eight sections of $\beta$-folded structures and are responsible for the enzyme activity and its sorption at the membrane surface, and also interact with regulators of lipid nature and calcium ions [11]. The amino acid sequence, tertiary structure and functions of this domain are similar to those of the $\mathrm{C}_{2}$-like domain of $\alpha$-toxin from Clostridium perfringens, on whose structure the lipoxygenase molecular model is based [16]. The similarity of the amino acid sequence and topology typical of polycystine-1, lipoxygenase and $\alpha$-toxin enabled to unite these proteins in the PLAT-domain family that is related to the $\mathrm{C}_{2}$ family $[17,18]$. Most of proteins, whose composition includes the $\mathrm{C}_{2}$-domain, are involved in the transduction of signals and membrane traffic including proteins that are implicated in the production of lipid secondary messengers (phospholipase $\mathrm{A}_{2}$, phospholipase $\mathrm{C}_{\mathrm{s}}$, phosphatidilinositole-3kinase and in phosphorylation of other proteins (protein kinase C) [19-21]. That is the reason why LOX is referred to as "signal" enzyme that executes catalysis in the state associated with membrane structures $[16,19,22]$. It was established that the G. max section LOX-1 which is composed of 15 amino acid residues and localized between the last section of the $\beta$-folded structure in the $\mathrm{N}$-domain and the first spiral of the catalytic $\mathrm{C}$-domain may undergo proteolysis by trypsin involving a rupture of the connection between Lys-277 and Ser-278. This process is associated with the formation of a less stable but more active "mini" - LOX having molecular weight of $60 \mathrm{kDa}[23,24]$.

\section{Products of lipoxygenase catalytic activity}

The plant lipoxygenase family catalyzes regioand stereospecific addition of molecular oxygen to 1,4-cis,cis-pentadiene fragment of linoleic, linolenic and $\alpha$-linolenic acids. A hydroperoxide product resulting from this process contains a conjugated cis-trans complex that is produced through the migration of a double link during the catalytic cycle $[5,6,11]$. Linoleic acid oxidation is the first part of a branching enzyme cascade, as a result of which there are biologically active compounds - oxylipins produced. They are involved in the formation of plant organism responses to abiotic and biotic stresses effects, regulation of ageing and apoptosis $[7,8$, 10, 25-29]. Lipoxygenase substrates are free polyunsaturated fatty acids which content increases after stress effects $[5,6,8]$. Most of lipoxygenases oxidize linoleic and linolenic acids in C-9 or C-13 positions produced there after 9- and 13-hydroperoxides 
which initiate at least six enzyme pathways (Fig. 1). The LOX biosynthesis pathway in plants includes a few parallel branches named after six enzymes of the corresponding branch as allene oxide synthase (AOS), allene oxide cyclase (AOC), hydroperoxide lyase (HPL), divinyl ether synthase, peroxygenase, epoxy alcohol synthase, and others in which various biologically active metabolites are produced. On the HPL pathway 9-hydroperoxylinoleat is transformed to C9-aldehydes and C9-aldoacids, and 13-hydroperoxylinoleat or 13-hydroperoxylinolenat to C6aldehydes and $\mathrm{C} 12$-aldoacids. The ketolic pathway involving AOS is brought about only by 13 -LOX. The AOC pathway results in JA production. One more branch of pathways that involve 9- and 13-LOX is production of divinyl ethers, particularly colnellenic and etherolenic acids. Synthesis of hydroxyand epoxy-derivatives of PUFA by peroxygenase is one more LOX-pathway branch that is synthesis of monomeric substrates of heteropolymer cutin - the main component of protection covering for plant overground organs - cuticle. [5, 6, 8]. Lipoxygenase substrates are both free oxygenic fatty acids and fatty acids that are included in reserve thriacylglycerols, phospholipids and galactolipids [11]. In PUFAs deoxygenation oxygen acts as the second substrate. Supply of PUFAs and oxygen to the LOX active center is assumed to occur through two hollows. But how and where PUFAs molecules are added to the enzyme active center was not revealed. However, it was demonstrated that electrostatic interaction between the PUFAs carboxylic group and positively charged amino acid residue of LOX is a determining factor in the enzyme-substrate complex production [30]. Primary products of lipoxygenase activity PUFA-hydroperoxides are lipoxin and hepoxilin predecessors. As a result of branching reactions there are oxylipins synthesized that express the synthesis of proteins and enzymes as well as plant antibiotics involved in detoxication under pathogenic attack [5-8]. The oxylipin family includes JA [31]. Jasmonates are implicated in the regulation of seed germination, pollen development, tuber formation, plant ageing, ethylene synthesis $[9,10,32,33]$. JA is involved in the transduction of signal as a response to biotic and abiotic stress effects [33] and along with ethylene it is responsible for the systemic response formation [34]. JA and methyl jasmonates affect concentrations of vitamin $\mathrm{C}$ - the most widespread antioxidant in plants [35]. Jasmonates were found in all plant organs: the highest concentrations were revealed in young intensively growing tissues of shoot tips, root tips, unripe fruits and young leaves [33]. Jasmonates were shown to conjugate with glucose and amino acids [36] and due to that these compounds are preserved and transported [33]. Mechanical damages and pathogenic infections cause a marked increase in concentrations of some oxylipins that makes it possible to identify them in plant tissues. Arabidopsis thaliana (L.) Heynh. infected by a pathogenic fungus Verticillium longisporum (C. Stark) Karapapa showed an increase in the content of some compounds among which there were oxo-phytodienoic acid (OPDA), dinor-OPDA, 9,12,13-threehydroxy-10,15-octadecadienoic and 9,12,13-threehydroxy-10-octadecanoic acids involved in the immunity formation [37]. Physiologically active plant oxylipins (2E)-dodecene-1,12-dicarboxylic acid (traumatic acid) and 12-oxo-trans-10-dodecenoic acid (traumatin) are also able to induce cell division and formation of callus in damaged sites $[1,8]$. Plant tissue disintegration led to the release of volatile $\mathrm{C}_{6}$ and $\mathrm{C}_{9}$-compounds characterized by a specific smell of newly-cut grass. $\mathrm{C}_{6}$-compounds - hexenals and hexenols belong to the most important antimicrobial and fungicidal agents that provide a primary defense against pathogens [38]. Tobacco plant infection by Golovinomyces cichoracearum (DC.) V. P. Heluta resulted in some increase in the 2(E)-hexenal content [39]. Botrytis cinerea Pers. infection caused the production of (3Z)- and (2Z)-hexenals, (3Z)-hexenol and (3Z)-hexenilacetat, which inhibited the development of a fungal infection in tissues of Solanum lycopersicum L. [40]. Volatile $\mathrm{C}_{9}$-compounds (2E)-nonenal and (3Z)-nonenal with the scent of fresh cucumber [4] were produced as a result of mechanical damages [41] and retarded pathogen action [42].

\section{LOX localization and activity}

In most of cells the lipoxygenase metabolic pathway begins in the plasmolemma and further proceeds in the cytoplasm. During lipase-catalyzed reactions (phospholipase $\mathrm{A}_{2}$ in particular) membrane lipids (among which phospholipids) release linoleic and linolenic fatty acids that are substrates of the lipoxygenase signaling system. The 9- and 13-LOXs pathways were shown to be spatially separated (Fig. 2). Thus, 13-lipoxygenase pathway occurs in chloroplasts while that of 9-lipoxygenase - in cytosol [6]. 9-hydroperoxide production is associated primarily with the cytoplasmic membrane [43, 44]. 9-LOX activity is also localized in membranes of 


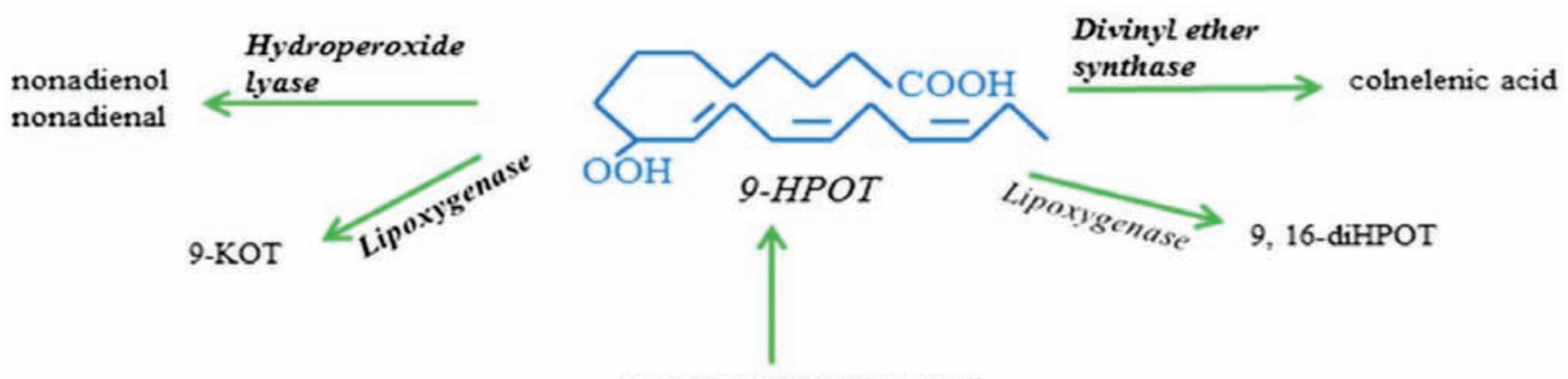

9-LIPOXYGENASE

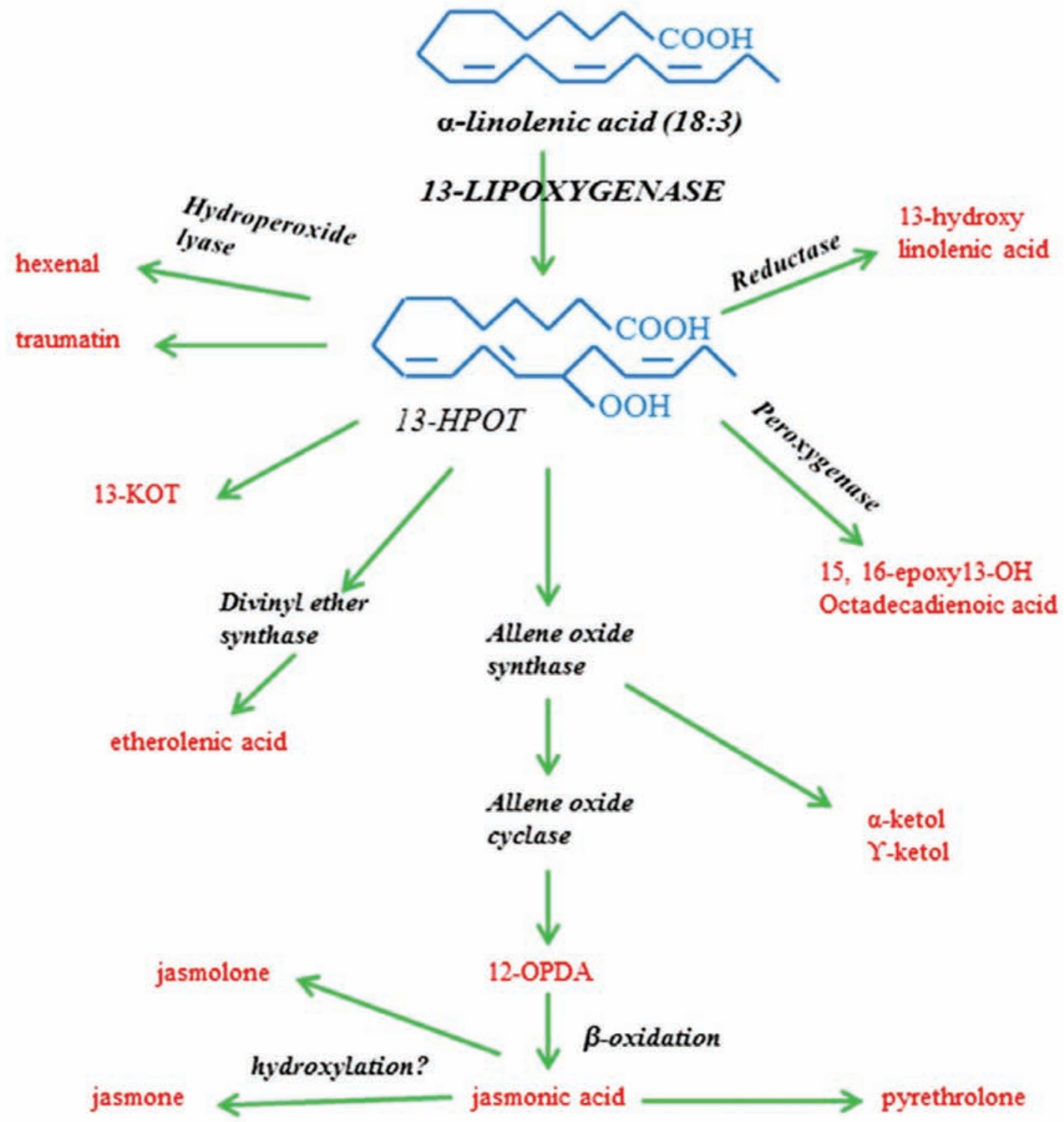

Fig. 1. The LOX-pathway (9-HPOT - (10E,12Z)-9-hydroperoxy-10,12,15- octadecatrienoic acid; 9-KOT (10E,12Z)-9-keto-10,12,15 octadecatrienoic acid; 13-HPOT - (10E,12Z)-13-hydroperoxy-10,12,15-octadecatrienoic acid; 13-KOT - (10E,12Z)-13-keto-10,12,15-octadecatrienoic acid; 12-OPDA - 12-oxo-10,15-phytodienoic acid) [Adapted from Porta H., Rocha-Sosa M., 2002] 
microsomes and mitochondria [45, 46]. Specific for enzymes lipoxygenases cascade AOS and HPL are associated with lipid drops and involved in lipid drops oxidation and release of lipid products into cytosol [5]. In potato tubers 9-AOS is localized in amyloplasts and leucoplasts [47] while in Petunia inflata leaves it is in tonoplasts [48]. 9-HPL is localized in microsomes of almond leaves [49]. Like 13-LOX all known 13-AOS, except AOS of Parthenium argentatum A. Gray. leaves, are associated with chloroplast membranes [50] and plastoglobules [51].

Most of 13-LOX products are related with chloroplast internal and external thylakoid membranes $[5,6,8]$. 13-HPL, AOS and AOC enzymes, whose substrates are products of 13-LOX oxidation of linoleic and linolenic acids, were shown to be localized in chloroplast internal and external membranes (Fig. 2) $[6,8,38]$. In the presence of $\mathrm{Ca}^{2+}$ ions some lipoxygenases can be transferred from cytoplasms and be bound with chloroplast membranes [52].

The JA synthesis was found to begin in chloroplasts which contain polyene fatty acids that are released during LOX activity rise. The JA first cycle predecessor - 12-OPDA is generated in chloroplasts. Further OPDA changes occur in peroxisomes. OPDA is transported to these organelles by fatty acid special cassette transporter PXA1 (peroxisomal ABC transporter 1). Residue product (+)-JA may be converted to (+)-7-iso-JA [9]. One phase of the JA conversion occurs in cytosol and that is the JA conjugation with amino acid isoleucine or methylation resulting in methyl jasmonate (Me-JA). An additional source of the intermediate substrate for the JA synthesis called "arabidopside" - galactolipid etherified with OPDA that is produced as a response to a wound and whose synthesis involves LOX-2 was found in A. thaliana cells [9]. OPDA that is implicated in JA transformations is released with the participation of galactolipase. JA- [53] or Me-JA-mediated [54] induction of lipoxygenase genes expression that increases the rate of linoleate and linolenate oxidation serves as an important mechanism of lipoxygenase metabolism promotion.

JA and some derivatives of oxygenic octadecanoic acid and hexadecanoic acid derivatives, which content significantly increases under stress conditions, belong to the key molecules of signaling and play an important role in plant stress tolerance induction $[55,56]$. Jasmonates and oxylipins are regarded as components of the mobile systemic signaling, when plants are wounded $[57,58]$. The JA involvement in mobile signal induction is confirmed by its synthesis localization in vascular bundles. It is also proved by the presence of prosystemin and systemin generation in cells of vascular bundle parenchyma primarily in the main leaf rib as well as by the JA synthesis in vessel cells. The analysis based on hybridization in situ and immunochemical methods demonstrated that prosystemin mRNA is present in parenchyma cell phloem [59]. Normally, JA and its methyl ether are produced from linoleic and linolenic acids as response to cell mechanical damages. JA is transported to wounded remote sites along the phloem while a volatile compound methyl jasmonate - by air. Me-JA volatile molecules were reported to execute the function of "alarm" signal and are able to convey information on hazard even to plants of different species [8]. Me-JA is thought to be a mobile signal that plays an important role during allelopathic interactions between individual plants [60]. After getting into the cell Me-JA is hydrolyzed to JA that activates plant defense responses. JA and Me-JA may act as elicitors and show synergistic interactions with other biotic elicitors to induce defense reactions [61].

\section{Regulation of lipoxygenase signaling system activity}

One of the phases of lipoxygenase metabolism control is effected through the regulation of activity of phospholipases A and desaturases - enzymes that synthesize and release PUFAs from phospholipids. Gene expression of lipoxygenases and cytochrome oxides (CYP74) is regulated by JA and its derivatives $[4,8,62]$. Enhancement of AOS genes transcription in cells and increase in AOC activity occur when leaves are wounded [63]. Promoters of many genes of the enzyme family cytochrome oxidases were revealed to have elements sensitive to stress signals by JA, SA and ethylene [63, 64]. Level of HPL gene transcription rose in response to pathogen attacks and mechanical wounds but in contrast to AOC the enzyme synthesis was not induced by Me-JA treatment [64]. A quick release of HPL-products after mechanical wounds indicates that the plant constitutive enzyme and its synthesis de novo are not required under conditions of stress effects. HPL is activated by a substrate contact that takes place after membranes destruction. Meanwhile, the enzyme is on the membrane or transported to a wounded site. One of the versions is the presence of the HPL predecessor that is activated after cutting of the N-ter- 


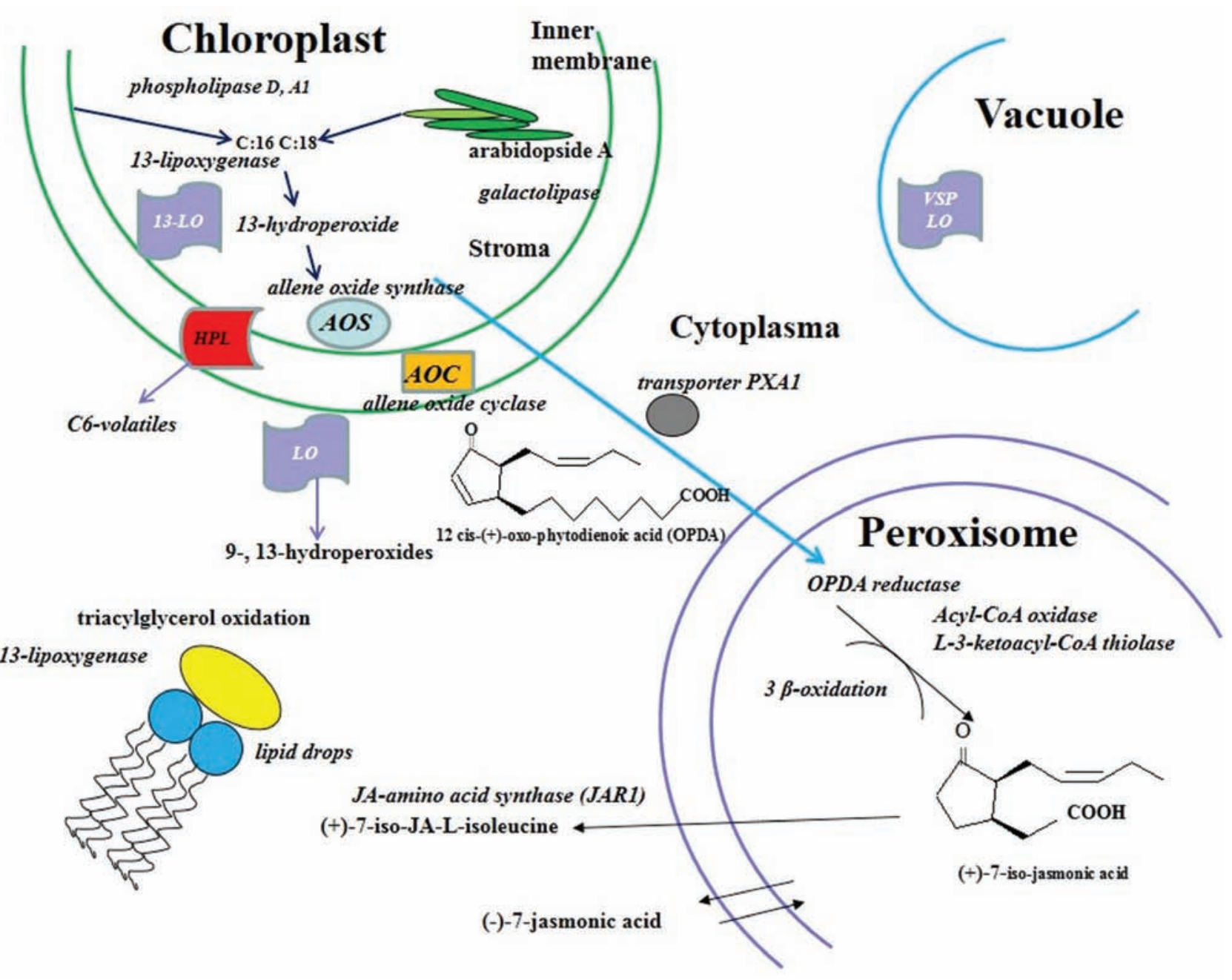

Fig. 2. It is a possible model of LOX activity compartmentalization in the plant cell (AOS - allene oxide synthetase; HPL - hydroperoxide lyase; AOC - allene oxid cyclase; VSP LO - vacuolar lipoxygenase; 13-LO chloroplast associated lipoxygenase; LO - cytoplasmic lipoxygenase). The plant 9- and 13-LOX pathways are spatially separated. The 13-LOX pathway is localized mainly in chloroplasts, 9-LOX - in cytosol. The initial stages of JA biosynthesis occur in chloroplasts, where appropriate enzymes are localized and they are completed by three $\beta$-oxidations in peroxisomes, JA is conjugated with amino acids in cytoplasm. Chloroplast $A O S, A O C$, and HPL are localized on internal and external membranes, respectively. Cytoplasma LOX are involved in lipid drops oxidation. Some plants showed LOX activity localization in vacuoles

minal sequence. Thus, Medicago sativa L. HPL activity increased after deletion of the first 22 amino acid residues of the N-terminal [65]. 13-HPL genes expression was detected in the plant overground part while that of 9-HPL - in the root one. HPL organ specificity correlates with an appropriate organ specificity of LOX. There was found a correlation between the HPL activity and chlorophyll content. Thus, the maximum activity was observed in unripe pepper fruits whereas during ripening the enzyme activity significantly decreased [66].
Different cell types were revealed to differ in the level of AOS and HPL gene expressions. AOS gene expression occurred in all tomato plant organs whereas HPL genes were activated only in leaves and flowers [67]. Expression tissue specificity was indicative of a key role of AOS in the regulation of plant various organs and tissues development. Profiles of AOS and HPL gene expressions in the same organs overlap [64].

Regulation pattern of the JA synthesis is complex and multilevel (Fig. 3). Under the influence of 
ethylene, elicitors, mechanical wounds, etc. the level of JA and OPDA significantly rises thereby provoking an increase in AOS activity [68]. JA and ethylene can positively affect the synthesis of each other during a defense mechanism activation and ageing [68]. In dicotyledons the AOS accumulation is induced by SA. An exogenous SA treatment caused OPDA accumulation in arabidopsis [68]. The JA synthesis in arabidopsis inhibited SA at the stage of OPDA production that is explained by a quick utilization of JA in SA-treated tissues and by the pattern of JA synthesis localization.

The level of divinyl ether synthase (DES) gene expression, a different LOX-pathway of products transformation, is related with a pathogenic infection [38]. Thus, 48 hours after pepper infection by the Obuda pepper virus 18-fold increase in DES gene expression occurred [69] (Fig. 3).

\section{Lipoxygenase phylogeny}

Information on the LOX evolution was obtained following a search for DNA specific sequences in the database GenBank, Refseq, Uniprot, Ensembl [70]. As a key element DNA fragments encoding iron ligand production were used. LOXs sequences were detected in pro- and eucariots. However, no lipoxygenases were found in archeae, which is most probably an evidence of an exceptional specificity of their existence environment. Presence of LOX gene sequences in DNA molecules in some lower plants suggests that the lipoxygenase family emerged after the emergence of atmospheric oxygen on the earth [70]. LOXs were detected in ciano- and proteobacteria, animalcular unicellular red and green sea algae, amoebae, fungi, mosses, angiosperms and animals (Fig. 4). We identified for the first time the LOX activity in higher vascular spore-bearing plants of Equisetum arvense L. and water fern Salvinia natans (L.) All. [71, 72]. Unicellular organisms contain mostly one or two LOX isoforms. Cyanobacteria Acarzochloris marina, which were found to have 5 different DNA sequences that encode the LOXs synthesis, are an exception. A. thaliana have 6-LOX genes [70]. Some plant species were revealed to have more than 15 different DNA sequences responsible for the LOXs synthesis that is evidence of possible gene duplication in evolution [73]. However, there is no unified concept of a common LOXs predecessor [70]. LOXs occurrence in bacteria suggests a horizontal transfer of genes [6] because most of unicellular organisms are ether pathogens or sym- bionts that are in a close contact with plant and animal cells. However, the number and heterogeneity of lower organism LOXs isoforms indicate that the gene horizontal transfer is probably not the only reason of LOXs prokaryote presence. Pro- and eukaryote LOXs are most likely to originate from one common predecessor. Cyanobacteria are one of the most ancient forms of life on earth in which LOXs genes were found and the family origin is an indirect indicative of an ancient origin of these enzymes. According to the endosymbiosis theory cyanobacteria originate from chloroplasts [74]. Considering the possibility of plastid genes transfer to the nuclear genome [75] it can be assumed that LOXs are of plant origin because LOXs isoforms of modern plants are localized in the genome plastid sequence. LOXs were also discovered in tomato chloroplasts [70]. Transformation of the LOXs molecular action mechanism is of special interest. It is quite possible that the evolution of many iron-compatible proteins including lipoxygenase and desaturases involved in the lipoxygenase cascade has common features. As it is known the initial function of these proteins consists in the interception of molecular oxygen to reduce its toxicity. Intercepted oxygen was transferred to various substrates further on converted in more complex reaction chains. Although fatty acid hydroperoxides as substrates for oxylipin production existed before lipoxygenase emergence, the combination of two protein components in a reaction chain made this process more controlled and effective. Unsaturated fatty acids may in their turn be synthesized under anaerobic conditions without involvement of desaturases like it occurs today in some bacteria in which fatty acid synthases can produce a double connection in acyl chain synthesis [70].

\section{Lipoxygenases and their metabolites in stress tolerance formation}

Numerous defensive mechanisms are involved in the formation of plant responses to biotic and abiotic stress effects. Signaling systems that trigger the antistress compound synthesis are activated depending on a pathogen type and abiotic stress pattern. Signal molecules including JA, Me-JA, SA, ethylene, ABA and other metabolites may act independently or interact either synergistically or antagonistically [8]. They are organically implicated in a complex signaling net that enables plants to apply an optimal defense strategy against biotic and antibiotic stresses [76]. Numerous studies have shown that the LOX 

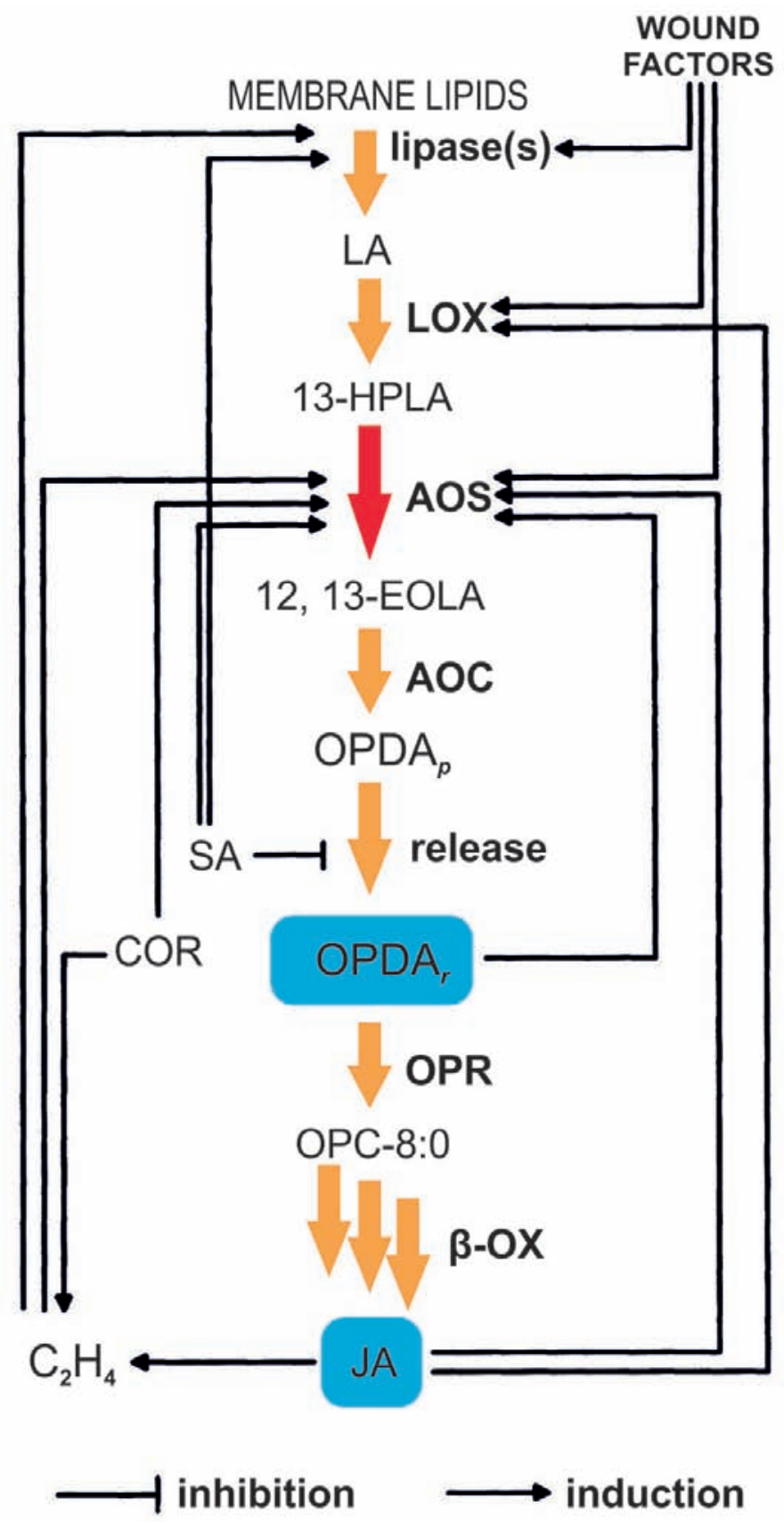

Fig. 3. Regulation of lipoxygenase signaling pathway (LOX - lipoxygenase; AOS - alene oxide synthase; AOC - allene oxide cyclase; OPR - OPDA reductase; $\beta$-Ox - oxidation; LA - $\alpha$-linolenic acid; 13-HPLA13(S)-hydroperoxylinolenic acid; 12, 13-EOLA - 12, 13-epoxylinolenic acid; OPDAp - 12-oxophytodienoic acid in plastids; OPDAr - OPDA released from plastids; OPC-8:0 - 3-oxo-2-(2(Z)-pentenyl) - cyclopropane1-octanoic acid; JA - jasmonic acid; SA - salicylic acid; COR - coronatine) [Adapted from Laudert, Weiler, 1998]. LOX-pathway is regulated by activity changes in lipases localized on membranes. The pattern of JA synthesis regulation is multi-level. Under conditions of defense mechanisms activation in stress JA and ethylene may stimulate mutual biosynthesis. When detrimentally affected, JA and OPDA levels are significantly increased as a result of AOS activity rise. AOS and OPDA accumulation induces SA. In dicotyledons JA synthesis is inhibited at the stage of OPDA production 


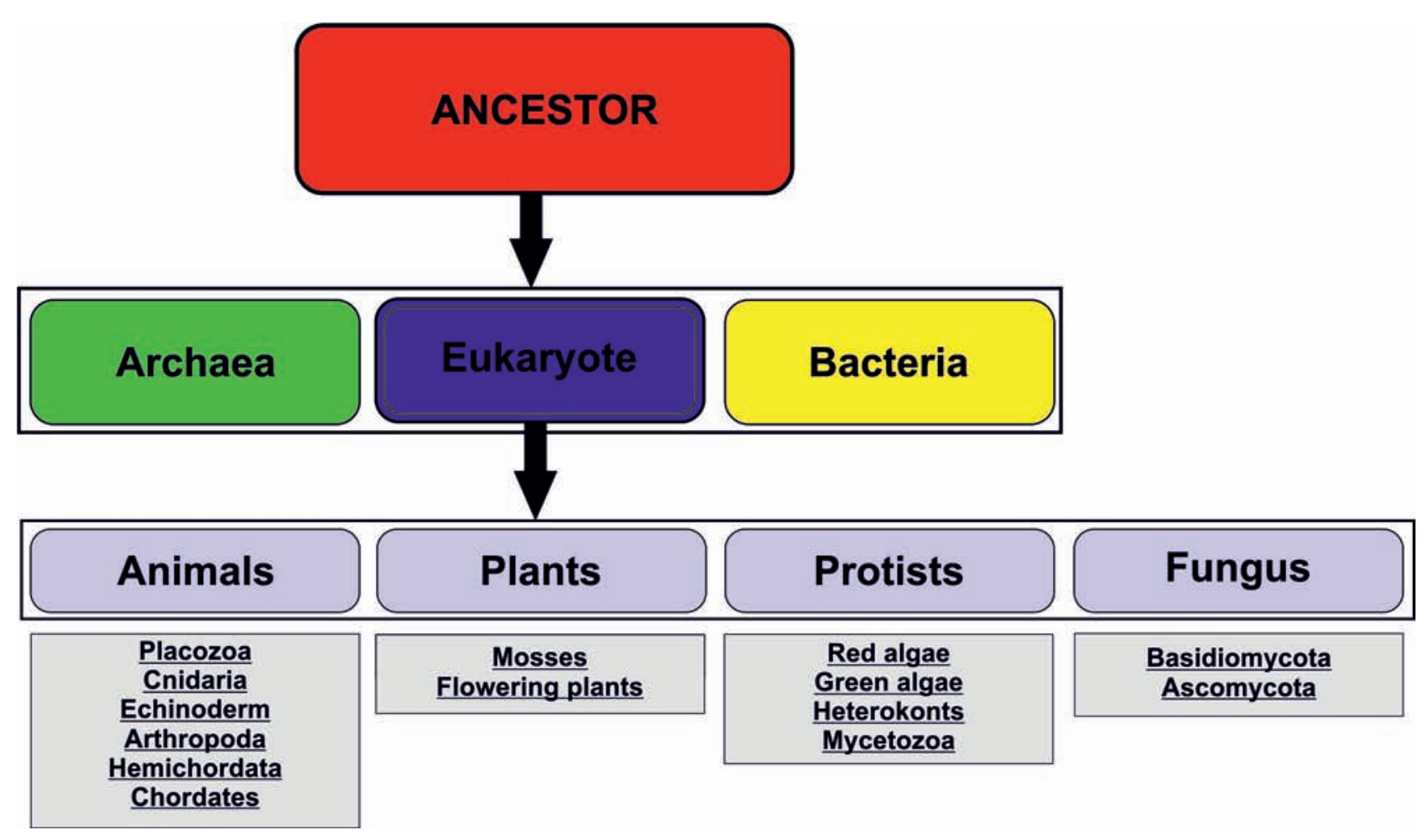

Fig. 4. Presence of lipoxygenase DNA sequences in pro- and eukaryotic [Adapted from Ivanon et al., 2010]. LOXs are widespread in nature. According to GenBank, Refseq, Uniprot, Ensembl data DNA sequences of were found in pro- and eukaryotes. No LOXs were detected in archaea that is due to the specificity of their habitat

activity increases with mechanical wounds [77], hyperthermia [78-80], ozone effect [26], elicitors [81], etc. LOX metabolism is intensified due to the transcription activation of genes that encode various enzymes. To date there is sufficient information to assume that the lipoxygenase pathway of membrane lipids conversion is an independent signaling pathway [4-8]. Like in other signaling systems the primary signal interaction with a plasmolemma receptor activates a membrane-bound protein that provides signaling along the signal circuit. Lipoxygenase circuit signals are enhanced by autocatalytic cycles involving calcium and calmodulin ions. Hydroperoxides that are produced in the plasmolemma from linoleate and linolenate transport calcium ions from outside to the inside of the cell [4-6, 82]. An increase in the cytoplasm calcium ion concentrations results in phospholipase A activation and release of PUFAs from phospholipids $[1,4,14]$. Normally, LOX as a cascade key enzyme regulates $L O X$ gene expression by means of cascade end products, for instance, jasmonate or methyl jasmonate that is typical of allosteric enzymes as is LOX $[53,54]$. Under autocata- lytic cycle conditions methyl jasmonate expresses genes of desaturase that catalyses linoleic acid conversion to linolenic acid [83]. Intermediate and end products of the LOX metabolism can activate protein kinases, send signal and provide its transduction. Although the molecular mechanisms of oxylipin activation of genes have been insufficiently studied the available data suggest that these compounds can express protein genes involved in plant stress tolerance formation $[7,8]$. Jasmonates belong to the group of the most-studied oxylipins implicated in the lipoxygenase signaling system. JA and Me-JA induce the synthesis of proteinase inhibitors and are involved in alkaloid release and accumulation, provide a selective suppression of the polypeptide synthesis [7, 58]. Generating the formation of active forms of oxygen and stimulating the synthesis of some protective compounds related with pathogenesis JA induces plant disease resistance [84]. JA was found to be involved in signaling from the surface of an infected cell to the nucleus as well as in intercellular signaling, it promotes the protective genes expression $[4$, $7,8,85]$. When mechanically wounded a plant forms 
a jasmonate-dependent response, its tissues desiccate and wounded sites accumulate ABA, expresses the cell cycle regulator ICK 1 which interacts with cycline D3 and suppresses the CDK-complexes activity [86]. JA and its predecessors take part in the complex multi-component signaling system of plant immunity formation. Initial phases of hormonal signaling by exogenous jasmonates are thought to be related with the regulation of $\mathrm{H}^{+}$and $\mathrm{Ca}^{2+}$ ions transport through cytoplasmic membrane [85]. It was shown that mechanical wounds in plants eaten out by animals cause a quick accumulation of JA and Me-JA [87], which occurs along with the activation of the key enzymes involved in these compounds biosynthesis $[63,88,89]$. Like a mechanical wound exogenous JA induces the expression of protective genes, which include gene-inhibitors of proteinases and gene phenylalanine ammonia lyase $[87,90]$. Inactivation of JA synthesis genes is accompanied by a suppression of a plant protective response. [91]. Mechanical wounds and systemin were revealed to activate the expression of proteinase inhibitors in tomato plants through a general signaling pathway involving JA $[5,10]$. JA is a stable end product of the fatty acid hydroperoxide metabolic pathway that implicates AOC [5]. However, there is evidence that in some plants signaling occurs either without this enzyme or with the enzyme activity being very low. It was shown that in infected oat leaves and rice shoots jasmonates are not involved in signaling [66]. Analysis of available experimental data demonstrates that molecular mechanisms of the action of jasmonates under abiotic stress conditions are very diverse and specific. Diversity of observed functions can be explained, at least partially, by the large number and variety of jasmonate signaling components, and by specific and overlapping functions of individual AOS branch metabolites. In leaves of many plants HPL is a dominant enzyme in hydroperoxide metabolism and due to this, volatile aldehydes that are products of HPLactivity execute signaling functions. Trans-2-hexenal was shown to induce the synthesis of phenylalanine ammonia lyase (PHAL), an enzyme that catalyzes lignin predecessor production and promotes thickening of cell walls. [92]. PHAL can catalyze SA, which provides the accumulation of hydrogen peroxide toxic for pathogens and production of plant antibiotics - phenylpropan phytoalexins. It was also shown that 4-hydroxy-2-nonenal induced the synthesis of glutation-S-transpherase that is implicated in elimination of substances toxic for plants [93]. It was established that oxylipins interact with biologi- cally active compounds of other signaling cascades, with phytohormones in particular. ABA was shown to affect positively the LOX activity when a plant is mechanically wounded [94]. However, under control conditions an ABA exogenous treatment inhibited lipoxygenase activity [95]. Exogenous ABA was found to stimulate lipoxygenase activity, promote JA production, activate peroxide oxidation of membrane lipids, contribute to the formation of tolerance when rice leaves are wounded [96]. A positive correlation between the ABA concentration and LOX transcript content was revealed in water-stressed plants [97]. Mechanical wounds lead to an increase of LOX activity, ABA and JA content $[98,99]$. ABA activates 9-LOX more than 13-LOX. Practically no expression of $L O X-2$ and $L O X-3$ genes occurred when soy leaves were treated with exogenous ABA. Exogenous $\mathrm{ABA}$ was shown to suppress the expression of $L O X-2$ genes in soy leaves. Under osmotic stress conditions the mRNA content of LOX-1 and LOX-2 increased, the enzyme and its activity rose, too [26]. It was revealed that under control conditions brassinosteroids caused a three - six-fold increase in the content of 9-LOX products [100]. In cold-stressed plants 2,4-epibrassinolide stimulated a significant enhancement of lipoxygenase activity [101]. Brassinosteroids that block a jasmonate inhibiting effect on root growth are involved in the signaling cascade of JA, which expresses DWF4 gene responsible for the synthesis of a key enzyme for brassinosteroids formation [102]. SA was shown to retard the production of 12-OPDA 10, 11-reductase (one of the key enzymes of JA synthesis) and also promote a local immunity due to OPDA accumulation. There were some isoforms of 12-OPDA 10,11-reductase detected, most of which did not catalyze OPDA regeneration but regenerated $\alpha$ - and $\beta$-saturated aldehydes derivatives of polyene fatty acids [4].

\section{LOX activity characteristics as stress tolerance molecular markers}

Plant successful adaptation to stress effects to a great extent depends on the effectiveness of defensive mechanisms, a significant role in their formation is played by signaling systems. LOX activity is regarded as a biological marker of the plant physiological state $[4,6,103]$. It was shown that following the effects of high temperatures, mechanical damages, pathogen infection the 13-LOX activity increases [26, 77, 81]. There was suppression of LOX activity after low temperature effects and also as a 
result of influence of polyamines, retinoids, ABA, epoxide derivatives of linoleate $[4,8]$. It was found that under salt stress conditions LOX activates lipid peroxide oxidation. Thus, some increase in the lipoxygenase activity under salt stress conditions was observed only in salt-tolerant plants [104].

Gene LOX expression was found to occur under low temperature conditions that is an indirect indicative of LOX involvement in the formation of plant adaptive responses to temperature stresses [105]. LOX enzyme activity increase resulting from low temperature effects is associated with phospholipase $\mathrm{D}$ which activity enhances due to stress factor action and that promotes membrane phospholipids degradation and release of PUFA - LOX substrate [106]. That correlates with an ability of phospholipase D product - phosphatidic acid - to affect directly LOX activity in vitro [107]. Cold and salt stresses effects on LOX activity differ. Thus, at the early phase $(4 \mathrm{~h})$ salt stress decreased the functional activity of LOX in corn and had virtually no effect on the activity of 13-LOX. Eventually the activity of 9-LOX returned to norm while that of 13-LOX reduced. Cold stress also suppressed the activity of 9-LOX while that of 13-LOX significantly increased that is indicative of a possible involvement of two different sites of the lipoxygenase cascade in the production of biologically active products due to abiotic stresses [108]. The pattern of changes of lipoxygenase activity levels following a short-term hyperand hypothermia was found to correlate with types of ecological strategies of individual plant species. Thus, the highest rates of lipoxygenase activity in leaves under the control conditions was observed in abiotic stress-tolerant seedlings of Rumex patienia L. that preserved activity after temperature conditions change. Seedlings of stressor-sensitive plant Festuca pratensis Huds. had the lowest rates of lipoxygenase activity in control and was characterized by a significant reduction in the enzyme activity after effects of high (by $31 \%$ ) and low (by $41 \%$ ) temperatures. LOX activity in leaves of heat-resistant ruder plant Amaranthus caudatus $\mathrm{L}$. rose by $76 \%$ due to high temperatures [109]. Studies of LOX activity in seedlings of cultivars Brassica napus contrast in their thermostability revealed that low temperatures reduced LOX activity in the heat-resistant cultivar by $34 \%$ while following a heat stress it remained eventually unchanged. However, after a heat stress the LOX activity in the cold-resistant cultivar was almost 2-fold reduced but after a cold stress no marked changes were observed [78]. Studies of short-term tempera- ture stress effects on the LOX activity in Triticum aestivum L. cultivars contrast in their thermostability indicated that both a high-temperature treatment $\left(+40{ }^{\circ} \mathrm{C}, 2 \mathrm{~h}\right)$ and a low positive temperature $\left(+4{ }^{\circ} \mathrm{C}\right.$, $2 \mathrm{~h}$ ) action promoted the heat-resistant cultivar LOX activity that testified to involvement of lipoxygenase cascade products in the formation of defense and stabilization mechanisms during a temperature stress [79]. At the same time, after a short-term hightemperature stress the activity of all 9-LOX isoforms in the cold-resistant cultivar increased. But 9-LOX ( $\mathrm{pH}$ 6.5) from roots and LOX-1 ( $\mathrm{pH}$ 7.0) from the seedling overground part showed the most significant increase. LOX activity reduction following low positive temperature effects was insignificant and that is consistent with the sign of cold resistance of the studied winter wheat cultivar [80]. The obtained data testify to possibility of using the enzyme activity characteristics as markers to investigate plant stress tolerance.

So, enzymes of the lipoxygenase family belong to evolutionary ancient compounds common in a wide range of organisms from pro- to eucaryotes. Lipoxygenases and lipoxygenase oxidation products of polyunsaturated fatty acids play a significant role in metabolism in plants, have influence on their growth and development, tolerance to biotic and abiotic stresses. LOXs are involved in signaling due to stressor effects and lipoxygenase activity characteristics may serve as molecular markers for the study of plant stress tolerance.

This work was supported by the special comprehensive interdisciplinary research program of the National Academy of Sciences of Ukraine "Molecular and cell biotechnologies for medicine, industry and agriculture purposes".

\section{ЛІПОКСИГЕНАЗИ ТА ЇХНІ МЕТАБОЛІТИ У ФОРМУВАННІ СТРЕСОСТІЙКОСТІ РОСЛИН}

\author{
Л. М. Бабенко ${ }^{1}$, М. М. Щербатюк ${ }^{1}$ \\ Т. Д. Скатерна ${ }^{2}$, I. В. Косаківська \\ ${ }^{1}$ Інститут ботаніки ім. М. Г. Холодного \\ НАН України, Київ; \\ ${ }^{2}$ Інститут біохімії ім, О. В. Палладіна \\ НАН України, Київ; \\ e-mail: lilia.babenko@gmail.com
}

В огляді наведено дані літератури останніх років із молекулярної ензимології ліпоксигеназ - 
протеїнів, задіяних у реакціях пероксидного окислення ліпідів і знайдених у тварин і рослин. Розглянуто й узагальнено існуючі уявлення щодо особливостей будови, каталітичних властивостей та функціонування ензимів родини ліпоксигеназ і продуктів їхньої каталітичної активності в рослинах. Обговорюються питання локалізації ензиму в рослинних клітинах і тканинах, еволюції та розповсюдження ліпоксигеназ, участі в утворенні сигнальних речовин, задіяних у формуванні адаптаційної відповіді на абіотичні та біотичні стресорні чинники, а також регуляції активності ліпоксигеназної (ЛОГ) сигнальної системи. Розглянуто елементи процесів рецепції та трансдукції сигналів ЛОГшляху до геному. Особливу увагу приділено жасмонатам, метаболітам аленоксидсинтазної гілки ліпоксигеназного каскаду. Ці метаболіти виявляють високу біологічну активність, повсюдно поширені в рослинних організмах, а також беруть участь у регуляції життєво важливих процесів. Проаналізовано результати щодо філогенії ліпоксигеназ, можливості існування спільного попередника сучасних ізоформ ензиму про/евкаріот. Подано окремі результати власних досліджень авторів стосовно використання показників каталітичної активності ліпоксигеназ як біологічних маркерів під час дослідження стресостійкості рослин.

К л ю ч о в і с ло в а: ліпоксигенази, структура, каталіз, жасмонова кислота, абіотичні/ біотичні стреси.

\section{ЛИПОКСИГЕНАЗЫ И ИХ МЕТАБОЛИТЫ В ФОРМИРОВАНИИ СТРЕССОУСТОЙЧИВОСТИ РАСТЕНИЙ}

\author{
Л. М. Бабенко ${ }^{1}$ Н. Н. Щербатюк ${ }^{1}$ \\ Т. Д. Скатерная ${ }^{2}$ И. В. Косаковская \\ ${ }^{1}$ Институт ботаники им. Н. Г. Холодного \\ НАН Украины, Киев; \\ ${ }^{2}$ Институт биохимии им. А. В. Палладина \\ НАН Украины, Киев; \\ e-mail: lilia.babenko@gmail.com
}

В обзоре приведены данные литературы последних лет по молекулярной энзимологии липоксигеназ - протеинов, задействованных в реакциях пероксидного окисления липидов, идентифицированных у животных и расте- ний. Рассмотрены и обобщены существующие представления об особенностях строения, каталитических свойствах и функционировании энзимов семейства липоксигеназ и продуктов их каталитической активности в растениях. Обсуждаются вопросы локализации энзима в растительных клетках и тканях, эволюции и распространения липоксигеназ, участия в образовании сигнальных соединений, задействованных в формировании адаптационных ответов на абиотические и биотические стрессорные факторы, а также регуляции активности липоксигеназной (ЛОГ) сигнальной сети. Рассмотрены элементы процессов рецепции и трансдукции сигналов ЛОГ-пути в геном. Особое внимание уделяется жасмонатам, метаболитам алленоксидсинтазной ветви липоксигеназного каскада. Эти метаболиты обладают высокой биологической активностью, повсеместно распространены в растительных организмах, а также участвуют в регулировании жизненно важных процессов. Проанализированы результаты о филогении липоксигеназ, возможности существования общего предшественника современных изоформ энзима у про- и эукариот. Приведены отдельные результаты собственных исследований авторов относительно использования показателей каталитической активности липоксигеназ как биологических маркеров при исследовании стрессоустойчивости растений.

К л ю ч е вы е с л о в а: липоксигеназы, структура, катализ, жасмоновая кислота, абиотические/биотические стрессы.

\section{References}

1. Tarchevsky IA. The metabolism of plants under stress. Kazan: Fen, 2001. 448 p. (In Russian).

2. Benková E. Plant hormones in interactions with the environment. Plant Mol Biol. 2016; 91(6): 597-615.

3. Dmitriev AP. Signalling molecules for activation of plant defense reactions in response to biotic stress. Russ J Plant Physiol. 2003; 50(3): 1-10.

4. Tarchevsky IA. Signalling system of plant cells. M.: Nayka, 2002. 294 p. (In Russian).

5. Feussner I, Wasternack C. The lipoxygenase pathway. Annu Rev Plant Biol. 2002; 53: 275297.

6. Porta H, Rocha-Sosa M. Plant lipoxygenases. Physiological and molecular features. Plant Physiol. 2002; 130(1): 15-21. 
7. Santino A, Taurino $\mathrm{M}$, De Domenico $\mathrm{S}$, Bonsegna S, Poltronieri P, Pastor V, Flors V. Jasmonate signaling in plant development and defense response to multiple (a)biotic stresses. Plant Cell Rep. 2013; 32(7): 1085-1098.

8. Savchenko TV, Zastrijnaja OM, Klimov VV. Oxylipins and plant abiotic stress resistance. Biochemistry (Mosc). 2014; 79(4): 362-375.

9. Babenko LM, Kosakivska IV, Skaterna TD. Jasmonic acid: a role in the regulation of biotechnology and biochemical processes in plants. Biotechnologia Acta. 2015; 8(2): 36-51.

10. Wasternack C, Hause B. Jasmonates: biosynthesis, perception, signal transduction and action in plant stress response, growth and development. An update to the 2007 review in Annals of Botany. Ann Bot. 2013; 111(6): 10211058.

11. Andreou A, Feussner I. Lipoxygenases - Structure and reaction mechanism. Phytochemistry. 2009; 70(13-14): 1504-1510.

12. Su C, Sahlin M, Oliw EH. A protein radical and ferryl intermediates are generated by linoleate diol synthase, a ferric hemeprotein with dioxygenase and hydroperoxide isomerase activities. J Biol Chem. 1998; 273(33): 2074420751.

13. Brash AR. Lipoxygenases: occurrence, functions, catalysis, and acquisition of substrate. J Biol Chem. 1999; 274(34): 23679-23682.

14. Liavonchanka A, Feussner I. Lipoxygenases: occurrence, functions and catalysis. J Plant Physiol. 2006; 163(3): 348-357.

15. Glickman MH, Klinman JP. Lipoxygenase reaction mechanism: demonstration that hydrogen abstraction from substrate precedes dioxygen binding during catalytic turnover. Biochemistry. 1996; 35(39): 12882-12892.

16. Kulkarni S, Das S, Funk CD, Murray D, Cho W. Molecular basis of the specific subcellular localization of the C2-like domain of 5-lipoxygenase. J Biol Chem. 2002; 277(15): 13167-13174.

17. Rizo J, Südhof TC. C2-domains, structure and function of a universal $\mathrm{Ca}^{2+}$-binding domain. J Biol Chem. 1998; 273(26): 15879-15882.

18. Chahinian H, Sias B, Carrière F. The C-terminal domain of pancreatic lipase: functional and structural analogies with c2 domains. Curr Protein Pept Sci. 2000; 1(1): 91-103.
19. Stahelin RV, Rafter JD, Das S, Cho W. The molecular basis of differential subcellular localization of $\mathrm{C} 2$ domains of protein kinase $\mathrm{C}$-alpha and group IVa cytosolic phospholipase A2. J Biol Chem. 2003; 278(14): 12452-12460.

20. Banci L, Cavallaro G, Kheifets V, MochlyRosen D. Molecular dynamics characterization of the C2 domain of protein kinase Cbeta. J Biol Chem. 2002; 277(15): 12988-12997.

21. Ochoa WF, Corbalán-Garcia S, Eritja R, Rodríguez-Alfaro JA, Gómez-Fernández JC, Fita I, Verdaguer N. Additional binding sites for anionic phospholipids and calcium ions in the crystal structures of complexes of the $\mathrm{C} 2$ domain of protein kinase calpha. J Mol Biol. 2002; 320(2): 277-291.

22. Hörnig C, Albert D, Fischer L, Hörnig M, Rådmark O, Steinhilber D, Werz O. 1-Oleoyl-2acetylglycerol stimulates 5-lipoxygenase activity via a putative (phospho)lipid binding site within the N-terminal C2-like domain. J Biol Chem. 2005; 280(29): 26913-26921.

23. Sudharshan E, Rao AG. Rapid method to separate the domains of soybean lipoxygenase-1: identification of the interdomain interactions. FEBS Lett. 1997; 406(1-2): 184-188.

24. Maccarrone M, Salucci ML, van Zadelhoff G, Malatesta F, Veldink G, Vliegenthart JF, Finazzi-Agrò A. Tryptic digestion of soybean lipoxygenase-1 generates a $60 \mathrm{kDa}$ fragment with improved activity and membrane binding ability. Biochemistry. 2001; 40(23): 6819-6827.

25. Göbel C, Feussner I, Schmidt A, Scheel D, Sanchez-Serrano J, Hamberg M, Rosahl S. Oxylipin profiling reveals the preferential stimulation of the 9-lipoxygenase pathway in elicitor-treated potato cells. J Biol Chem. 2001; 276(9): 6267-6273.

26. Maccarrone M, Melino G, Finazzi-Agrò A. Lipoxygenases and their involvement in programmed cell death. Cell Death Differ. 2001; 8(8): 776-784.

27. Taki N, Sasaki-Sekimoto $Y$, Obayashi T, Kikuta A, Kobayashi K, Ainai T, Yagi K, Sakurai N, Suzuki H, Masuda T, Takamiya K, Shibata D, Kobayashi Y, Ohta H. 12-oxophytodienoic acid triggers expression of a distinct set of genes and plays a role in woundinduced gene expression in Arabidopsis. Plant Physiol. 2005; 139(3): 1268-1283. 
28. Vellosillo T, Martínez M, López MA, Vicente J, Cascón T, Dolan L, Hamberg M, Castresana C. Oxylipins produced by the 9-lipoxygenase pathway in Arabidopsis regulate lateral root development and defense responses through a specific signaling cascade. Plant Cell. 2007; 19(3): 831-846.

29. Mosblech A, Feussner I, Heilmann I. Oxylipins: structurally diverse metabolites from fatty acid oxidation. Plant Physiol Biochem. 2009; 47(6): 511-517.

30. Schwarz K, Walther M, Anton M, Gerth C, Feussner I, Kuhn H. Structural basis for lipoxygenase specificity. Conversion of the human leukocyte 5-lipoxygenase to a 15-lipoxygenating enzyme species by sitedirected mutagenesis. J Biol Chem. 2001; 276(1): 773-779.

31. Delporte A, Lannoo N, Vandenborre G, Ongenaert M, Van Damme EJ. Jasmonate response of the Nicotiana tabacum agglutinin promoter in Arabidopsis thaliana. Plant Physiol Biochem. 2011; 49(8): 843-851.

32. Ballaré CL. Jasmonate-induced defenses: a tale of intelligence, collaborators and rascals. Trends Plant Sci. 2011; 16(5): 249-257.

33. Piotrowska A, Bajguz A. Conjugates of abscisic acid, brassinosteroids, ethylene, gibberellins, and jasmonates. Phytochemistry. 2011; 72(17): 2097-2112.

34. Van der Ent S, Van Wees SC, Pieterse CM. Jasmonate signaling in plant interactions with resistance-inducing beneficial microbes. Phytochemistry. 2009; 70(13-14): 1581-1588.

35. Suza WP, Avila CA, Carruthers K, Kulkarni S, Goggin FL, Lorence A. Exploring the impact of wounding and jasmonates on ascorbate metabolism. Plant Physiol Biochem. 2010; 48(5): 337-350.

36. Tamogami S, Rakwal R, Aqrawal GK. Interplant communication: Airborne methyl jasmonate is essentially converted into JA and Witt stock, JAIle activating jasmonate signaling pathway and VOCs emission. Biochem Biophys Res Commun. 2008; 376(4): 723-727.

37. Floerl S, Majcherczyk A, Possienke M, Feussner K, Tappe H, Gatz C, Feussner I, Kües U, Polle A. Verticillium longisporum infection affects the leaf apoplastic proteome, metabolome, and cell wall properties in Arabidopsis thaliana. PLoS One. 2012; 7(2): e31435.
38. Hughes RK, De Domenico S, Santino A. Plant cytochrome CYP74 family: biochemical features, endocellular localisation, activation mechanism in plant defence and improvements for industrial applications. Chembiochem. 2009; 10(7): 1122-1133.

39. Quaglia M, Fabrizi M, Zazzerini A, Zadra C. Role of pathogen-induced volatiles in the Nicotiana tabacum-Golovinomyces cichoracearum interaction. Plant Physiol Biochem. 2012; 52: 9-20.

40. Copolovici L, Kännaste A, Pazouki L, Niinemets U. Emissions of green leaf volatiles and terpenoids from Solanum lycopersicum are quantitatively related to the severity of cold and heat shock treatments. J Plant Physiol. 2012; 169(7): 664-672.

41. Stumpe M, Göbel C, Demchenko K, Hoffmann M, Klösgen RB, Pawlowski K, Feussner I. Identification of an allene oxide synthase (CYP74C) that leads to formation of alpha-ketols from 9-hydroperoxides of linoleic and linolenic acid in below-ground organs of potato. Plant $J$. 2006; 47(6): 883-896.

42. Huang FC, Schwab W. Cloning and characterization of a 9-lipoxygenase gene induced by pathogen attack from Nicotiana benthamiana for biotechnological application. BMC Biotechnol. 2011; 11: 30.

43. Royo J, Vancanneyt G, Pérez AG, Sanz C, Störmann K, Rosahl S, Sánchez-Serrano JJ. Characterization of three potato lipoxygenases with distinct enzymatic activities and different organ-specific and wound-regulated expression patterns. J Biol Chem. 1996; 271(35): 2101221019.

44. Kimura H, Yokota K. Characterization of metabolic pathway of linoleic acid 9-hydroperoxide in cytosolic fraction of potato tubers and identification of reaction products. Appl Biochem Biotechnol. 2004; 118(1-3): 115132.

45. Droillard MJ, Rouet-Mayer MA, Bureau JM, Lauriere C. Membrane-Associated and Soluble Lipoxygenase Isoforms in Tomato pericarp (Characterization and Involvement in Membrane Alterations). Plant Physiol. 1993; 103(4): 12111219.

46. Braidot E, Petrussa E, Micolini S, Tubaro F, Vianello A, Macrì F. Biochemical and immunochemical evidences for the presence of 
lipoxygenase in plant mitochondria. $J$ Exp Bot. 2004; 55(403): 1655-1662.

47. Kongrit D, Jisaka M, Kobayasi K, Nishigaichi Y, Nishimura K, Nagaya T, Yokota K. Molecular cloning, functional expression, and tissue distribution of a potato sprout allene oxide synthase involved in a 9-lipoxygenase pathway. Biosci Biotechnol Biochem. 2006; 70(9): 21602168.

48. $\mathrm{Xu} \mathrm{Y}$, Ishida $\mathrm{H}$, Reisen $\mathrm{D}$, Hanson MR. Upregulation of a tonoplast-localized cytochrome P450 during petal senescence in Petunia inflata. BMC Plant Biol. 2006; 6: 8.

49. Mita G, Quarta A, Fasano P, De Paolis A, Di Sansebastiano GP, Perrotta C, Iannacone R, Belfield E, Hughes R, Tsesmetzis N, Casey R, Santino A. Molecular cloning and characterization of an almond 9-hydroperoxide lyase, a new CYP74 targeted to lipid bodies. J Exp Bot. 2005; 56(419): 2321-2333.

50. Farmaki T, Sanmartín M, Jiménez P, Paneque M, Sanz C, Vancanneyt G, León J, SánchezSerrano JJ. Differential distribution of the lipoxygenase pathway enzymes within potato chloroplasts. J Exp Bot. 2007; 58(3): 555-568.

51. Schaller A, Stintzi A. Enzymes in jasmonate biosynthesis - structure, function, regulation. Phytochemistry. 2009; 70(13-14): 1532-1538.

52. Cho K, Han Y, Woo JC, Baudisch B, Klösgen RB, Oh S, Han J, Han O. Cellular localization of dual positional specific maize lipoxygenase-1 in transgenic rice and calcium-mediated membrane association. Plant Sci. 2011; 181(3): 242-248.

53. Jensen AB, Poca E, Rigaud M, Freyssinet G, Pagès $M$. Molecular characterization of L2 lipoxygenase from maize embryos. Plant $\mathrm{Mol}$ Biol. 1997; 33(4): 605-614.

54. Eiben HG, Slusarenko AJ. Complex spatial and temporal expression of lipoxygenase genes during Phaseolus vulgaris (L.) development. Plant J. 1994; 5(1): 123-135.

55. Howe GA, Jander G. Plant immunity to insect herbivores. Annu Rev Plant Biol. 2008;59:41-66.

56. Kazan K, Manners JM. Jasmonate signaling: toward an integrated view. Plant Physiol. 2008; 146(4): 1459-1468.

57. Ryan CA, Pearce G. Systemin: a polypeptide signal for plant defensive genes. Annu Rev Cell Dev Biol. 1998; 14: 1-17.

58. Kolupaev YuE, Ystreb TA, Lugovaya AA. Jasmonates role in the adaptation of plants to action for abiotic stressors. Fiziol Rasten Genet. 2016; 48(2): 95-111. (In Russian).

59. Narváez-Vásquez J, Ryan CA. The cellular localization of prosystemin: a functional role for phloem parenchyma in systemic wound signaling. Planta. 2004; 218(3): 360-369.

60. Seo HS, Song JT, Cheong JJ, Lee YH, Lee YW, Hwang I, Lee JS, Choi YD. Jasmonic acid carboxyl methyltransferase: a key enzyme for jasmonate-regulated plant responses. Proc Natl Acad Sci USA. 2001; 98(8): 4788-4793.

61. Stuhlfelder C, Mueller MJ, Warzecha H. Cloning and expression of a tomato cDNA encoding a methyl jasmonate cleaving esterase. Eur $J$ Biochem. 2004; 271(14): 2976-2983.

62. Holková I, Bezáková L, Bilka F, Balažová A, Vanko M, Blanáriková V. Involvement of lipoxygenase in elicitor-stimulated sanguinarine accumulation in Papaver somniferum suspension cultures. Plant Physiol Biochem. 2010; 48(10-11): 887-892.

63. Sivasankar S, Sheldrick B, Rothstein SJ. Expression of allene oxide synthase determines defense gene activation in tomato. Plant Physiol. 2000; 122(4): 1335-1342.

64. Howe GA, Lee GI, Itoh A, Li L, DeRocher AE. Cytochrome P450-dependent metabolism of oxylipins in tomato. Cloning and expression of allene oxide synthase and fatty acid hydroperoxide lyase. Plant Physiol. 2000; 123(2): 711-724.

65. Noordermeer MA, Feussner I, Kolbe A, Veldink GA, Vliegenthart JF. Oxygenation of (3Z)-alkenals to 4-hydroxy-(2E)-alkenals in plant extracts: a nonenzymatic process. Biochem Biophys Res Commun. 2000; 277(1): 112-116.

66. Grechkin AN. Hydroperoxide lyase and divinyl ether synthase. Prostaglandins Other Lipid Mediat. 2002; 68-69: 457-470.

67. Froehlich JE, Itoh A, Howe GA. Tomato allene oxide synthase and fatty acid hydroperoxide lyase, two cy tochrome P450s involved in oxylipin metabolism, are targeted to different membranes of chloroplast envelope. Plant Physiol. 2001; 125(1): 306-317.

68. Laudert D, Weiler EW. Allene oxide synthase: a major control point in Arabidopsis thaliana octadecanoid signalling. Plant J. 1998; 15(5): 675-684.

69. Gullner G, Ktinstler M, Kiraly L, Pogany M, Tobias I. Up-regulated expression of lipoxy- 
genase and divinyl ether synthase genes in pepper leaves inoculated with Tobamoviruses. Physiol Mol Plant Pathol. 2010; 74(5-6): 387393.

70. Ivanov I, Heydeck D, Hofheinz K, Roffeis J, O'Donnell VB, Kuhn H, Walther M. Molecular enzymology of lipoxygenases. Arch Biochem Biophys. 2010; 503(2): 161-174.

71. Babenko LM, Voytenko LV, Skaterna TD, Musatenko LI. Lipoxygenase activity in Equisetum arvense L. ontogenesis. Fiziol Rast Genet. 2014; 46(1): 37-44. (In Ukrainian).

72. Babenko, LM, Skaterna, TD, Kosakivska, IV. Lypoxigenase activity of Salvinia natans (L.) All. in ontogenesis. Dopov Nac Akad Nauk Ukr. 2016; 8: 101-108. (In Ukrainian).

73. Shin JH, Van K, Kim DH, Kim KD, Jang YE, Choi BS, Kim MY, Lee SH. The lipoxygenase gene family: a genomic fossil of shared polyploidy between Glycine max and Medicago truncatula. BMC Plant Biol. 2008; 8: 133.

74. Sagan L. On the origin of mitosing cells. $J$ Theor Biol. 1967; 14(3): 255-274.

75. Timmis JN, Ayliffe MA, Huang CY, Martin W. Endosymbiotic gene transfer: organelle genomes forge eukaryotic chromosomes. Nat Rev Genet. 2004; 5(2): 123-135.

76. Lorenzo O, Solano R. Molecular players regulating the jasmonate signalling network. Curr Opin Plant Biol. 2005; 8(5): 532-540.

77. Fabbri AA, Fanelli C, Reverberi M, Ricelli A, Camera E, Urbanelli S, Rossini A, Picardo M, Altamura MM. Early physiological and cytological events induced by wounding in potato tuber. J Exp Bot. 2000; 51(348): 12671275.

78. Kosakivska IV, Babenko LM, Ustinova AYu, Skaterna TD. The influence of temperature conditions on lipoxygenase activity in seedling of rape Brassica napus var. Oleifera. Dopov Nac Akad Nauk Ukr. 2012; 6: 134-137.(In Ukrainian).

79. Kosakivska IV, Babenko LM, Skaterna TD, Ustinova AYu. Influence of hypo- and hyperthermia on lipoxygenase activity, content of pigments and soluble proteins in Triticum aestivum L. cv. Yatran 60 seedlings. Fiziol Rast Genet. 2014; 46(3): 212-220. (In Ukrainian).

80. Babenko LM, Kosakivska IV, Akimov YuA, Klymchuk DO, Skaternya TD. Effect of temperature stresses on pigment content, lipoxygenase activity and cell ultrastructure of winter wheat seedlings. Genet Plant Physiol. 2014; 4(1-2): 117-125.

81. Chandra S, Heinstein PF, Low PS. Activation of Phospholipase A by Plant Defense Elicitors. Plant Physiol. 1996; 110(3): 979-986.

82. Kolupaev Yu.E, Karpets Yu. V. Formation of adaptive responses of plants to abiotic stressful Action. K.: Osnova, 2010. 352 p. (In Russian).

83. Nishiuchi $T$, Hamada $T$, Kodama H, Iba K. Wounding changes the spatial expression pattern of the arabidopsis plastid omega-3 fatty acid desaturase gene (FAD7) through different signal transduction pathways. Plant Cell. 1997; 9(10): 1701-1712.

84. Cohen Y, Gisi U, Niderman T. Local and systemic protection against Phytophthora infestans induced in potato and tomato plants by jasmonic acid and jasmonic-methyl-ester. Phytopathology. 1993; 83(10): 1054-1062.

85. Ozeretskovskaya OL, Vasyukova NI, Chalenko GI, Gerasimova NG, Revina TA, Valueva TA. Wound healing and induced resistance in potato tubers. Appl Biochem Microbiol. 2009; 45(2): 199-203. (In Russian).

86. Birkenmeier GF, Ryan CA. Wound signaling in tomato plants. Evidence that aba is not a primary signal for defense gene activation. Plant Physiol. 1998; 117(2): 687-693.

87. Campos-Vargas R, Saltveit ME. Involvement of putative chemical wound signals in the induction of phenolic metabolism in wounded lettuce. Physiol Plant. 2002; 114(1): 73-84.

88. Strassner J, Schaller F, Frick UB, Howe GA, Weiler EW, Amrhein N, Macheroux P, Schaller A. Characterization and cDNA-microarray expression analysis of 12-oxophytodienoate reductases reveals differential roles for octadecanoid biosynthesis in the local versus the systemic wound response. Plant J. 2002; 32(4): 585-601.

89. Stenzel I, Hause B, Maucher H, Pitzschke A, Miersch O, Ziegler J, Ryan CA, Wasternack C. Allene oxide cyclase dependence of the wound response and vascular bundle-specific generation of jasmonates in tomato - amplification in wound signalling. Plant J. 2003; 33(3): 577-589.

90. Moore JP, Paul ND, Whittaker JB, Taylor JE. Exogenous jasmonic acid mimics herbivoreinduced systemic increase in cell wall bound peroxidase activity and reduction in leaf expansion. Funct Ecol. 2003; 17(4): 549-554. 
91. Park JH, Halitschke R, Kim HB, Baldwin IT, Feldmann KA, Feyereisen R. A knock-out mutation in allene oxide synthase results in male sterility and defective wound signal transduction in Arabidopsis due to a block in jasmonic acid biosynthesis. Plant J. 2002; 31(1): 1-12.

92. Koshio K, Takahashi H, Ota Y. Induction of browning of male flowers of Cryptomeria japonica by treatment with fatty acids: mechanism and the role of trans-2-hexenal. Plant Cell Physiol. 1995; 36(8): 1511-1517.

93. Fukuda A, Nakamura Y, Ohigashi H, Osawa T, Uchida K. Cellular response to the redox active lipid peroxidation products: induction of glutathione S-transferase P by 4-hydroxy-2nonenal. Biochem Biophys Res Commun. 1997 Jul 18;236(2):505-9.

94. Peña-Cortés H, Fisahn J, Willmitzer L. Signals involved in wound-induced proteinase inhibitor II gene expression in tomato and potato plants. Proc Natl Acad Sci USA. 1995; 92(10): 41064113.

95. Royo J, Vancanneyt G, Pérez AG, Sanz C, Störmann K, Rosahl S, Sánchez-Serrano JJ. Characterization of three potato lipoxygenases with distinct enzymatic activities and different organ-specific and wound-regulated expression patterns. J Biol Chem. 1996; 271(35): 2101221019.

96. Roychoudhury A, Basu S, Sengupta DN. Effects of exogenous abscisic acid on some physiological responses in a popular aromatic indicia rice compared with those from two traditional nonaromatic indicia rice cultivars. Acta Physiol Plant. 2009; 31(5): 915-926.

97. Deluc LG, Quilici DR, Decendit A, Grimplet J, Wheatley MD, Schlauch KA, Mérillon JM, Cushman JC, Cramer GR. Water deficit alters differentially metabolic pathways affecting important flavor and quality traits in grape berries of Cabernet Sauvignon and Chardonnay. BMC Genomics. 2009; 10: 212.

98. Turner JG, Ellis C, Devoto A. The jasmonate signal pathway. Plant Cell. 2002; 14 Suppl: S153-S164.

99. Zhang KW, An Y, Hu Z. Relationship between lipoxygenase and ABA and JA in wounded signal transduction of healthy populous seedlings. Forest Research. 2005; 18(3): 300-304.

100. Fedina EO, Karimova FG, Chechetkin IR, Tarchevsky IA, Khripach VA. Contribution of lipoxygenase metabolism to the brassinosteroid signaling pathway. Dokl Biochem Biophys. 2004; 395: 80-83.

101. Kopich VN, Kretynin SV, Kharchenko OV, Litvinovskaya RP, Chashina NM, Khripach VA. Effect of 24-epibrassinolide on lipoxygenase activity in maize seedlings under cold stress. Biopolym Cell. 2010; 26(3): 218224. (In Ukrainian).

102. Ren C, Han C, Peng W, Huang Y, Peng Z, Xiong X, Zhu Q, Gao B, Xie D. A leaky mutation in DWARF4 reveals an antagonistic role of brassinosteroid in the inhibition of root growth by jasmonate in Arabidopsis. Plant Physiol. 2009; 151(3): 1412-1420.

103. Pokotylo IV, Kolesnikov YS, Derevyanchuk MV, Kharitonenko AI, Kravets VS. Lipoxygenases and plant cell metabolism regulation. Ukr Biochem J. 2015; 87(2): 41-55. (In Ukrainian).

104. Ben-Hayyim G, Gueta-Dahan Y, AvsianKretchmer O, Weichert $\mathrm{H}$, Feussner I. Preferential induction of a 9-lipoxygenase by salt in salt-tolerant cells of Citrus sinensis L. Osbeck. Planta. 2001; 212(3): 367-375.

105. Yang XY, Jiang WJ, Yu HJ. The expression profiling of the lipoxygenase $(L O X)$ family genes during fruit development, abiotic stress and hormonal treatments in cucumber (Cucumis sativus L.). Int J Mol Sci. 2012; 13(2): 2481-2500.

106. Mao LC, Wang GZ, Zhu CG, Pang HQ. Involvement of phospholipase D and lipoxygenase in response to chilling stress in postharvest cucumber fruits. Plant Sci. 2007; 172(2): 400-405.

107. Skaterna TD, Kharchenko OV. Effect of phosphatidic acid on the reaction of linoleic acid oxidation by 5-lipooxygenase from potato nodules. Ukr Biokhim Zhurn. 2008; 80(3): 2130. (In Ukrainian).

108. Kopich VM, Kharchenko OV. The influence of salt stress and abscisic acid on the activity of lipoxygenase corn. Dopov Nac Akad Nauk Ukr. 2011; 12: 148-152. (In Ukrainian).

109. Kosakivska IV, Konturska OO, Ustinova AYu. Hypo- and hyperthermia effect on lipoxygenase activity in leaves of plants with different ecological strategies. Ukr Botan Zhurn. 2011; 68(6): 883-889.(In Ukrainian).

Received 20.09.2016 